Revue des patrimoines

43 | 2021

Des écoles d'art académiques aux écoles d'art : des collections et des lieux, un patrimoine à valoriser

\title{
LE NUMERO EN BREF - Des écoles d'art académiques aux écoles d'art : des collections et des lieux, un patrimoine à valoriser
}

THE ISSUE IN BRIEF -- Academies and art schools: places and collections for teaching art, enhancing a heritage

\section{Morwena Joly-Parvex}

\section{(2) OpenEdition}

Journals

\section{Édition électronique}

URL : http://journals.openedition.org/insitu/30121

DOI : 10.4000/insitu.30121

ISSN : 1630-7305

\section{Éditeur}

Ministère de la Culture

\section{Référence électronique}

Morwena Joly-Parvex, « LE NUMERO EN BREF - Des écoles d'art académiques aux écoles d'art : des collections et des lieux, un patrimoine à valoriser », In Situ [En ligne], 43 | 2021, mis en ligne le,

consulté le 14 janvier 2021. URL : http://journals.openedition.org/insitu/30121 ; DOI : https://doi.org/ 10.4000/insitu.30121

Ce document a été généré automatiquement le 14 janvier 2021.

\section{c) (†) $९$}

In Situ Revues des patrimoines est mis à disposition selon les termes de la licence Creative Commons Attribution - Pas d'Utilisation Commerciale - Pas de Modification 4.0 International. 


\title{
LE NUMERO EN BREF - Des écoles d'art académiques aux écoles d'art : des collections et des lieux, un patrimoine à valoriser
}

\author{
THE ISSUE IN BRIEF -- Academies and art schools: places and collections for \\ teaching art, enhancing a heritage
}

Morwena Joly-Parvex

1 En Europe et particulièrement en France, le patrimoine des écoles d'art est aujourd'hui l'objet de nombreuses études. Alors qu'à la faveur de recherches menées sur la provenance ou la propriété d'œuvres qu'ils conservent des musées retrouvent et interrogent leurs liens avec les premières écoles d'art au xvIII ${ }^{\mathrm{e}}$ siècle, nombre de modèles, dont l'usage s'était perdu dans la seconde moitié $\mathrm{du} \mathrm{xx}^{\mathrm{e}}$ siècle, sont redécouverts. Chercheurs, professionnels de l'histoire de l'art et du patrimoine apportent leurs expertises afin de reconstituer les collections initiales et de restituer le sens dont elles sont porteuses au sein d'une histoire de la pédagogie artistique.

2 Ce numéro d'In Situ. Revue des patrimoines a été conçu dans l'idée de rassembler des réflexions plurielles, élaborées par des professionnels de divers horizons. Il ne s'agit pas seulement d'identifier et de reconstituer l'histoire du patrimoine matériel, collections et édifices, mais d'ouvrir la réflexion sur la dimension immatérielle de ce patrimoine et notamment sur la pédagogie artistique, son histoire et son incarnation.

3 Grace à des articles monographiques consacrés à l'histoire de collections attachées à des écoles d'art et académies ou à des contributions qui abordent le sujet de manière transverse et synthétique, le lecteur découvre la considération changeante portée à ces modèles rassemblés au fil des siècles dont certains ensembles ont fait l'objet d'inventaires, à la manière d'une collection, au point parfois de bénéficier d'une exposition de type muséal. La question des frontières entre école d'art et institution 
muséale est ici posée et envisagée de manière différenciée en fonction de l'histoire de chaque nation européenne.

4 L'ambition pédagogique ne se manifeste pas seulement à travers les collections, elle s'exprime aussi parfois dans les édifices conçus spécifiquement pour accueillir ces écoles. Amphithéâtres, décors ou architectures deviennent alors des manifestes pédagogiques. Cette dimension immatérielle du patrimoine des écoles d'art fait l'objet d'un récent programme de recherche mené par l'École des chartes, qui vise à collecter les gestes de la transmission. Il aura l'ambition et le mérite de valoriser le patrimoine "absent » de ces écoles, entre autres le rituel du dessin d'après le modèle vivant, central dans la pédagogie artistique.

5 In Europe, and especially in France, Art schools heritage is currently the focus of numerous studies. Thanks to research conducted on the history or the ownership of works they preserve, some museums are restoring and examining their ties with the first art schools in the $18^{\text {th }}$ century. A number of models, whose usage had been lost in the second half of the $20^{\text {th }}$ century, are being rediscovered. Researchers, art history and heritage professionals provide their expertise in order to gather the initial collections and reflect the meaning they have to offer within the history of artistic education.

6 This issue of In Situ. Revue des patrimoines was created with the idea of gathering mainly reflections, elaborated by professionals with various backgrounds. It is not only a matter of identifying and reconstructing the history of tangible heritage, collections and buildings, but also of broadening the reflection on the intangible dimension of this heritage, and particularly on artistic education, its history, its embodiment.

7 Thanks to monographs dedicated to the history of collections attached to art schools and academies or to contributions that address the subject in a cross-functional and in a summary way, the reader discovers the changing consideration given to those models collected over the centuries, which some ensembles were inventoried, like a collection would. Sometimes they even have benefited from a museum exhibition. The issue of borderlines between art school and museum institution had been raised here and considered in a differentiated way in accordance to the history of each European nation.

8 The educational ambition is not only visible through the collections, but sometimes, it also expresses itself in the buildings specifically designed to accommodate schools. Auditoriums, decorations or architectures become then educational manifestos. This intangible dimension of art schools heritage is the subject of a recent research program carried out by the École des Chartes that aims to collect the teaching inherited skills. The purpose is to enhance the "missing" heritage of those schools, amongst others, the ritual of drawing from a live model, the key point of art education. 